\title{
Perception of body image and nutritional status in adolescents of public schools
}

\author{
Percepção da imagem corporal e estado nutricional em adolescentes de escolas públicas \\ Percepción de la imagen corporal y el estado nutricional en adolescentes de escuelas públicas
}

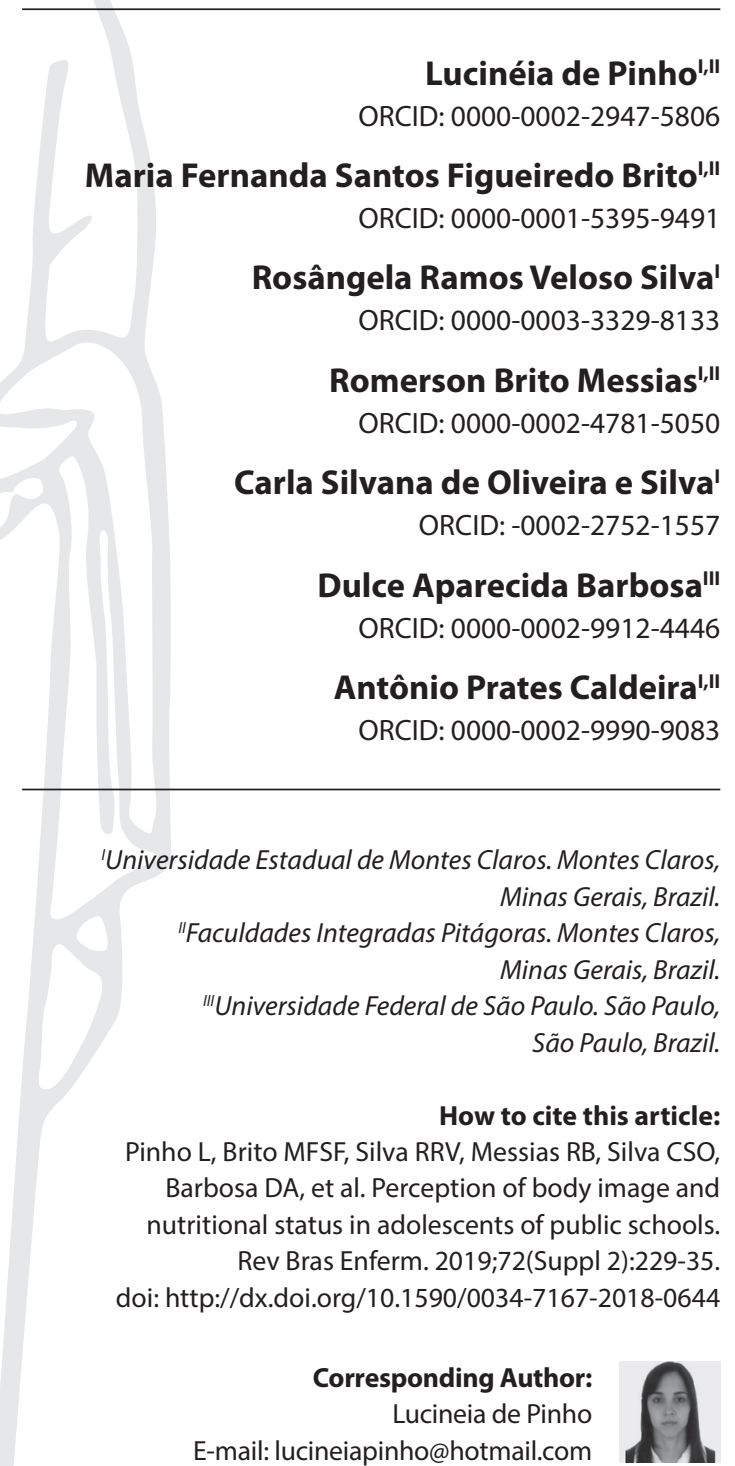

Submission: 08-17-2018 Approval: 04-13-2019

\section{ABSTRACT}

Objective: To assess body image dissatisfaction among adolescents from Northern Minas Gerais. Method: This is a cross-sectional study with adolescents of both sexes, enrolled in the sixth to ninth year in the municipal public education network. A questionnaire was used, composed of sociodemographic and body image variables, which was obtained through a scale of silhouette figures. The anthropometric measurements of weight and height were performed to estimate body mass index. The correlation between the classification of the body mass index and the body image of adolescents was estimated through weighted Kappa. Results: A total of 535 adolescents participated, and $24.5 \%$ had different classifications between the real and ideal body image. The Kappa index for the classification of body image was $0.51,0.58$ and 0.32 for the total of adolescents, girls and boys, respectively. Conclusion: Public school adolescents are dissatisfied with their self-body image.

Descriptors: Adolescent; Body Image; Adolescent Health; Nutritional Status; Body Mass Index.

\section{RESUMO}

Objetivo: Avaliar a insatisfação da imagem corporal entre adolescentes do norte de Minas Gerais. Método: Trata-se de estudo transversal realizado com adolescentes de ambos os sexos, matriculados do sexto ao nono ano na rede pública municipal de ensino. Foi utilizado um questionário, composto por variáveis sociodemográficas e de imagem corporal, obtida por meio de uma escala de figuras de silhuetas. Foram realizadas as medidas antropométricas de peso e altura, para o cálculo do índice de massa corporal. A concordância entre a classificação do índice de massa corporal e a imagem corporal dos adolescentes foi estimada por meio do Kappa ponderado. Resultados: Participaram 535 adolescentes, sendo que $24,5 \%$ possuíam classificação diferente entre a imagem corporal real e ideal. O índice Kappa para a classificação da imagem corporal foi de 0,51, 0,58 e 0,32 para o total de adolescentes, meninas e meninos, respectivamente. Conclusão: Os adolescentes de escolas públicas possuem insatisfação da autoimagem corporal. Descritores: Adolescente; Imagem Corporal; Saúde do Adolescente; Estado Nutricional; Índice de Massa Corporal.

\section{RESUMEN}

Objetivo: Evaluar la insatisfacción con la imagen corporal de los adolescentes de la región norte de Minas Gerais. Método: Se trata de un estudio transversal, en el cual participaron adolescentes de ambos sexos, matriculados del $6 .^{\circ}$ al $9 .^{\circ}$ año en la red pública municipal de enseñanza. Se utilizó un cuestionario, que constó de variables sociodemográficas y de imagen corporal, obtenida por medio de una escala de figuras de siluetas. Se obtuvieron las medidas antropométricas de peso y altura para estimar el índice de masa corporal. La concordancia entre la clasificación del índice de masa corporal y la imagen corporal de los adolescentes se calculó mediante el índice Kappa ponderado. Resultados: De los 535 adolescentes participantes, un $24,5 \%$ tenía una clasificación diferente entre la imagen corporal real y la ideal. Para la clasificación de la imagen corporal, el índice Kappa fue de 0,51, 0,58 y 0,32 para el total de adolescentes, niñas y niños, respectivamente. Conclusión: Los adolescentes de escuelas públicas presentaron una autoimagen insatisfecha con su cuerpo. Descriptores: Adolescente; Imagen Corporal; Salud del Adolescente; Estado Nutricional; Índice de Masa Corporal. 


\section{INTRODUCTION}

Adolescence is a period of fast morphological and psychosocial changes that greatly influences body perception ${ }^{(1)}$. Among adolescents, the desire and the constant search for a physical characteristic different from reality are becoming more common ${ }^{(2)}$, which may result in body image dissatisfaction ${ }^{(3-4)}$.

The high body image dissatisfaction may be facilitated by the access to media resources, especially those related to social networks, to which adolescents are frequently exposed, becoming a risk group ${ }^{(2-3,5)}$. There is an idealization of a perfect body in current societies, which, when not achieved, might generate body image disorders, in addition to effects in health and behavior of adolescents ${ }^{(6-8)}$.

Surveillance of body image satisfaction is necessary, since adolescents may perceive their own body differently from its real size, shape and weight. Such behavior, according to its magnitude, may contribute to the occurrence of eating ${ }^{(2,47)}$ and mental ${ }^{(9)}$ disorders, which might compromise their social relations ${ }^{(2)}$ and quality of life. These disorders may manifest through the dissatisfaction with body image and even suicidal thoughts and attitudes ${ }^{(3)}$. In this sense, body image dissatisfaction may be a risk factor for the development of psychopathologies and as a mediator of the relation between nutritional status and emotional health ${ }^{(3,9)}$.

Considering the negative results in health, it is important to understand the body dissatisfaction among young people. To this end, health and education professionals need to be alert to changes in behavior related to search for the stereotypical body model, since they commonly begin in childhood and adolescence. An assessment of body dissatisfaction can be performed by the scale of silhouettes, which, in recent years, is one of the most used techniques in populational studies, due to its practicality. The instrument consists in drawings (silhouettes) of human figures and offers information regarding body image perception ${ }^{(10)}$. The initial approach is fundamental for forwarding the individual to a specialized health service, which will allow early diagnosis and, consequently, the prognosis for adolescents ${ }^{(0,11)}$.

Knowledge on body image dissatisfaction among adolescents of different contexts is necessary, since body image perception might be influenced by the socioeconomic and cultural condition $^{(3-8,12)}$. Thus, regional data collection may contribute to directing public policy measures that promote the health of adolescents and that consider this issue.

\section{OBJECTIVE}

To assess the association between self body image dissatisfaction and the nutritional status among adolescents in the North of Minas Gerais.

\section{METHOD}

\section{Ethical aspects}

The study respected the ethical principles for researches involving human beings. The research project was approved by the Research Ethics Committee of the State University of Montes
Claros (Unimontes), protocol no. 3016. An informed consent form was used, which was signed by the legal guardian of the adolescent, authorizing their participation. All adolescents signed an Assent Form, in which their clarified their consent to participate in the research.

\section{Design, location of the study and study period}

This is a cross-sectional study, performed with adolescents of both sexes, enrolled in the municipal public education network of Montes Claros in the North of Minas Gerais. Data was collected in the second half of 2011.

\section{Population or sample; inclusion and exclusion criteria}

Sampling size was defined through calculation for finite populations, based on the following criteria: a) total number of students -6269 elementary students, enrolled from the sixth to ninth year in schools in the urban area of the municipality;

a) b) $95 \%$ confidence level; $5 \%$ sampling error; d) correction factor for sampling design ("deff") equal to 1.5;

b) prevalence of body dissatisfaction of $26 \%$, considering the data from studies with adolescents in the state ${ }^{(13)}$. An increase of $20 \%$ in the sampling size was also established to compensate possible losses (non-response rate). The participation of at least 510 adolescents was estimated.

The sample was selected by probabilistic clustering. In the first stage, school selection was performed through selection method with probabilities proportional to size. Then, the selection of school classes was performed by simple random sampling. In each of the selected classes, all adolescents were invited to answer the research questionnaire.

The inclusion criteria of the research were: age from 10 to 19 years, according to the chronological limits of adolescence defined by the World Health Organization (WHO), and to have a signed Informed Consent Form (ICF). Adolescents who delivered incomplete questionnaires, pregnant and those with physical or mental disabilities were excluded from the study.

\section{Study variables}

Data collection was performed in the school environment during the adolescents' class period, by properly trained researchers. The adolescents were assessed regarding their sociodemographic characteristics, nutritional status and body image. In a private room in the school, the student received a self-administered questionnaire composed of sociodemographic variables: sex, age, year, session, socioeconomic status and parents'schooling level. Anthropometric measurements of weight and height were performed, according to the Guideline Protocol for Collection and Analysis of Anthropometric Data in Health Services of the Sistema de Vigilância Alimentar e Nutricional (SISVAN - Food and Nutritional Monitoring System $)^{(14)}$.

Body weight was measured with a portable digital scale (Marte $\left.{ }^{\oplus}\right)$ with maximum capacity of $199.95 \mathrm{~kg}$, minimum capacity of $1 \mathrm{~kg}$ 
and precision of $50 \mathrm{~g}$, with adolescents wearing light clothes, barefoot and without coats. They stood in an orthostatic position, with arms extended beside the body, relaxed shoulders and keeping their head up and looking straight ahead. Height was measured with the aid of a vertical stadiometer (Altura exata ${ }^{\circledR}$ ), with a bilateral numerical scale of $35-213 \mathrm{~cm}$ and resolution of $0.1 \mathrm{~cm}$. To measure the height, the adolescents were barefoot, with touching heels, in upright position, leaning on the wall and with their head in the Frankfurt plane. Based on the anthropometric measurements of weight and height, the Body Mass Index (BMI) was calculated. Weight and height were measured in duplicate, and the average value obtained for each participant was used to calculate the BMI for age (in Z scores) in order to assess the nutritional status. Calculations were performed using the software Diet Pró ${ }^{\circledR}$. Adolescents were classified regarding nutritional status, considering the cut-off point: underweight ( $Z$ core $<-2)$, eutrophic ( $Z$ score from -2 and +1$)$ and overweight $(Z \text { score }<+1)^{(15)}$.

Information concerning body image were obtained through self-assessment, using the scale of silhouette figures for adolescents $^{(16)}$ and validated in Brazil ${ }^{(17)}$ (Figure 1).

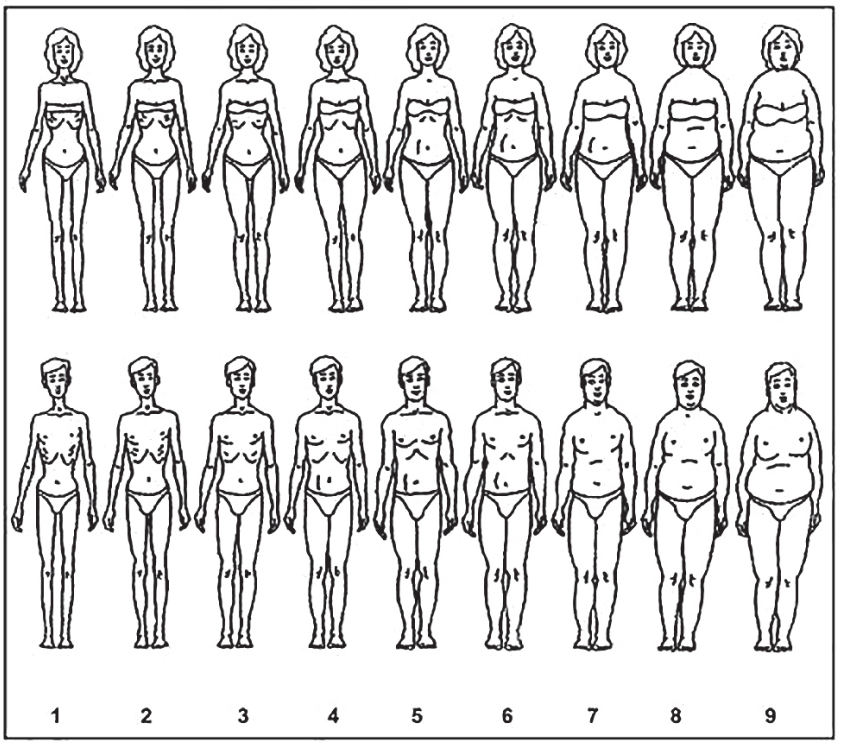

Figure 1 - Silhouette scale

For the analysis, the following criteria were established: underweight (silhouette 1); eutrophic (silhouettes 2-5); and overweight (silhouettes 6-9) ${ }^{(18)}$. Dissatisfaction with body image was established considering the difference of perception between the perceived and desired silhouette. To assess the body image, the real body appearance was subtracted from the ideal body appearance. When the variation was equal to zero, it was classified as satisfactory; and if it was different from zero, it was classified as dissatisfactory. If the difference was positive, it was a dissatisfaction due to excess weight; and, when negative, a dissatisfaction due to thinness ${ }^{(19)}$.

\section{Analysis of results and statistics}

In the data analysis, the statistical software SPSS $^{\circledR}$, version 19.0 for Windows, was used. Descriptive statistics was performed through absolute and relative frequency. To verify the associations between the studied variables, the Chi-squared test was used (x2), adopting a 5\% significance level.

\section{RESULTS}

A total of 535 adolescents participated of the study, being $68.0 \%$ ( $N=364)$ female and $32.0 \%(n=171)$ male, aged from 11 to 17 years. Approximately $90 \%$ of the adolescents attended the morning session at school and were distributed between the sixth and ninth year. Regarding the socioeconomic situation, it was observed that $36.3 \%(n=194)$ of the families had an income higher than one minimum wage. Most parents had less than seven years of schooling. Concerning BMI, it was verified that $75.3 \%, 6.2 \%$ and $18.5 \%$ of the adolescents were classified as eutrophic, underweight and overweight, respectively. Regarding body image, it was verified that $60.4 \%$ of the adolescents were classified as satisfied, and $39.6 \%$ as dissatisfied (Table 1).

Table 1 - Characterization of adolescents from municipal public schools $(\mathrm{N}=535)$, Montes Claros, Minas Gerais, Brazil, 2015

\begin{tabular}{|c|c|c|}
\hline Variables & $\mathbf{n}$ & $\%$ \\
\hline \multicolumn{3}{|l|}{ Sex } \\
\hline Female & 364 & 68.0 \\
\hline Male & 171 & 32.0 \\
\hline \multicolumn{3}{|l|}{ Age (years) } \\
\hline $11-12$ & 130 & 24.3 \\
\hline $13-14$ & 307 & 57.4 \\
\hline $15-17$ & 98 & 18.3 \\
\hline \multicolumn{3}{|l|}{ Year } \\
\hline Sixth & 187 & 35.0 \\
\hline Seventh & 115 & 21.5 \\
\hline Eighth & 138 & 25.8 \\
\hline Ninth & 95 & 17.8 \\
\hline \multicolumn{3}{|l|}{ Session } \\
\hline Manhã & 480 & 89.7 \\
\hline Afternoon & 55 & 10.3 \\
\hline \multicolumn{3}{|c|}{ Household income in $\mathrm{MW}^{*}$} \\
\hline$\leq 1 \mathrm{MW}$ & 341 & 63.7 \\
\hline$>1 \mathrm{MW}$ & 194 & 36.3 \\
\hline \multicolumn{3}{|c|}{ Parent/guardian's schooling (years) } \\
\hline$>8$ & 203 & 37.9 \\
\hline $5-7$ & 220 & 41.1 \\
\hline $0-4$ & 112 & 21.0 \\
\hline \multicolumn{3}{|l|}{ Nutritional status } \\
\hline Underweight & 33 & 6.2 \\
\hline Eutrophic & 403 & 75.3 \\
\hline Overweight & 99 & 18.5 \\
\hline \multicolumn{3}{|l|}{ Body image } \\
\hline Satisfied & 323 & 60.4 \\
\hline Dissatisfied & 212 & 39.6 \\
\hline
\end{tabular}

In the analysis of distribution of young people by sex and body image, a higher prevalence of dissatisfaction was observed for women $(42.9 \%)$, with statistically significant differences regarding $\operatorname{sex}(p=0.026)$ (Figure 2). 


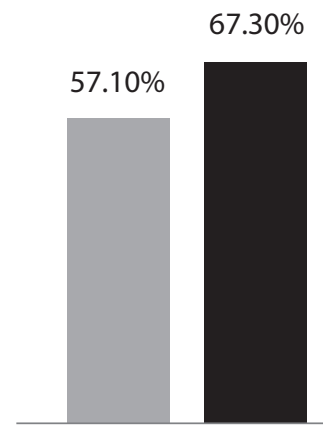

Satisfied
$42.90 \%$

$32.70 \%$

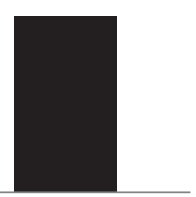

Dissatisfied

\section{Female Male}

Figure 2 - Distribution of young people by sex and satisfaction with body image

In the analysis of the satisfaction degree with body image between the sexes, a significant association was verified $(p<0.001)$. Male adolescents showed a higher proportion of dissatisfaction due to weight deficit (18.1\%), while female ones due to excess of weight (32.2\%) ( Table 2).

In this study, a statistically significant association was observed $(p<0.001)$ between nutritional status and the body image of the assessed adolescents. It was verified that low weight and overweight adolescents, $81.8 \%$ and $59.6 \%$, respectively, were dissatisfied with their body image. Among the adolescents with adequate weight, most classified themselves as satisfied (68.7\%) (Table 3).

Table 2 - Association between sex and degree of satisfaction with body image

\begin{tabular}{|c|c|c|c|}
\hline \multirow[b]{2}{*}{ Sex } & \multicolumn{3}{|c|}{ Classification of body image satisfaction } \\
\hline & $\begin{array}{c}\text { Dissatisfied } \\
\text { due to weight } \\
\text { deficit }\end{array}$ & Satisfied & $\begin{array}{l}\text { Dissatisfied due } \\
\text { to excess weight }\end{array}$ \\
\hline Female & 39 (10.7) & $208(57.1)$ & $117(32.2)$ \\
\hline Male & $31(18.1)$ & $115(67.3)$ & 25 (14.6) \\
\hline
\end{tabular}

Note: $P<0,001$

Table 3 - Association between the nutritional status and body image satisfaction

\begin{tabular}{lcc}
\hline $\begin{array}{l}\text { Nutritional } \\
\text { status }\end{array}$ & $\begin{array}{c}\text { Classification of body image satisfaction } \\
\text { Satisfied }\end{array}$ & Dissatisfied \\
\hline Underweight & $06(18.2)$ & $27(81.8)$ \\
Eutrophic & $277(68.7)$ & $126(31.3)$ \\
Overweight & $40(40.4)$ & $59(59.6)$ \\
\hline
\end{tabular}

Note: $P<0.001$.

\section{DISCUSSION}

In this study, it was possible to verify that almost half of publicschool adolescents in a municipality from the North of Minas Gerais showed body image dissatisfaction. A systematic literature review on body image of adolescents focused on the use of a silhouette scale showed that the prevalence of dissatisfactions with body image varied from $32.2 \%$ to $83 \%$, with a great heterogeneity among the studies ${ }^{(10)}$. A study performed with adolescents from Brazilian capitals observed a low correlation between the body image and nutritional status of the adolescent ${ }^{(1)}$. These results may be related to the fact that adolescence is a critical period for the development of body image, due to the several social, physical and psychological changes that occur in this stage of life ${ }^{(19)}$. In cities of different sizes and regardless of the age, adolescents have been dissatisfied with their body image $\mathrm{e}^{(1-6)}$. In adolescents, the concern with some aspect of their appearance might have important effects in their feelings and functionality, which makes them vulnerable to the occurrence of disorders linked to mental health ${ }^{(20)}$.

In relation to sex, in this study, it was concluded that most girls were dissatisfied with excess weight. International ${ }^{(21-22)}$ and national ${ }^{(23-24)}$ studies showed that there are more cases of overestimating body image or weight in girls. A recent study performed with 2765 adolescents in Europe ${ }^{(21)}$ concluded that body image dissatisfaction and weight control behavior are issues for girls in particular. This difference between real and ideal silhouette with higher incidence in girls may result in a differential diagnosis of body dysmorphic disorder, since it is more prevalent in women, beginning at the age between 15 and 30 years $^{(9)}$. The beauty standard currently imposed by media — valuing thinness — reinforces this condition, which may lead to the adoption of restrictive diets, regardless of the real need, and contribute to the occurrence and maintenance of low weight ${ }^{(24)}$, as well as for the compromise of eating habits ${ }^{(25)}$ and the presence of mental disorders ${ }^{(7)}$.

Among boys, the higher prevalence of dissatisfaction with body image was due to weight deficit. A study performed in the North of Minas Gerais ${ }^{(26)}$ observed that $39.5 \%$ of the researched male adolescents wished to increase their body size. This datum might be explained partially because boys wish to have bodies with greater muscle volume, possibly aspiring for a muscular and stronger body ${ }^{(5)}$. Other similar results confirm that girls usually wanted to decrease their body silhouette - dissatisfied with excess weight, commonly observed in this age group ${ }^{(23,27)}-$, while boys crave stronger bodies - dissatisfied with thinness ${ }^{(1,2,5,23)}$.

We have to consider that the investigation on the opinion on the body seems to be better when compared with the opinion on weight to express the perceptive dimension of body image ${ }^{(22,28)}$. This assumption was verified in a study performed with adolescents from Rio de Janeiro to assess the concordance between different body image indicators and body mass index. In this sense, the use of the body silhouette instrument is suitable for monitoring risk factors and protection for adolescents ${ }^{(29)}$.

In the analysis of association of body image with nutritional status, it was observed that a greater proportion of adolescents with low weight and excess weight was dissatisfied with body image. This condition may be a reflex of the exposure of adolescents to sociocultural and media influences, with the need to meet contemporary beauty standards, characterized by an unrealistic thinness for women and a muscular body for men ${ }^{(1)}$. Body dissatisfaction is associated to BMI for women and men, in such a way that the increase of BMI over time is associated with increased body dissatisfaction ${ }^{(30)}$.

Given the dissatisfaction with body image among adolescents, it is essential to monitor the nutritional status in this age group, mainly considering that these individuals are still growing and developing and are at risk of early introduction to diseases associated with weight deviations ${ }^{(1)}$. Additionally, the way adolescents 
perceive their own body image may lead to consequences in physical, mental and social dimensions. Satisfaction with body image is an important factor in the self-acceptance of adolescents and may result in inappropriate attitudes, which can compromise the overall health of the individual ${ }^{(2)}$. A study performed in the same city of this study observed that the negative perception of body weight was associated to violence behaviors ${ }^{(26)}$.

It also adds the possibility that body dissatisfaction may originate, in some adolescents, from the body dysmorphic disorder. This normally coexists with other mental disorders. Major depressive disorder affects $90 \%$ of these individuals throughout life; approximately $70 \%$ develop anxiety disorder and $30 \%$ psychotic disorder ${ }^{(19)}$. This aspect deserves to be investigated in future studies.

Given this context, the need for interventions by health professionals in the adolescence stage is evident in order to prevent that body image dissatisfaction result in the occurrence of psychical problems that are related to self-image and eating disorders ${ }^{(2,6,31-32)}$. In this way, school and family must be alert to signs of body image distortion in adolescents, having an important role in the identification of risk situations that need specialized professional treatment.

\section{Limitations of the study}

In this study, the following limitations should be considered: the application of questionnaires in the school environment might have been influenced by the environment and peers, and the assessment of adolescents in the context of municipal public-school scenarios, so that the data cannot be generalized.

\section{Contributions to the field of nursing, health or public policy}

This study confirmed the importance of knowing the body image of adolescents ${ }^{(32)}$. The body image assessment must be incorporated in the practice of health professionals, especially from nursing, with health promotion and protection actions for adolescents.

The nurse has an important role of educator and must promote reflections on body image and the effects of body dissatisfaction among adolescents, parents/guardians and teachers. In their practice, these professionals can stimulate the critical and reflexive consciousness of adolescents in empowerment for self-care with their body and health. Educational activities with guidance on knowledge and body perception, adoption and maintenance of healthy lifestyles and adequate use of social networks need to be incorporated into the school environment and in the teams of Family Health Strategy ${ }^{(7)}$. The constant monitoring of risk factors ${ }^{(29)}$, including measures of tracking and assessing the nutritional status of adolescents, must become a reality in the practice of the nurse in these scenarios, in addition to clinical consultations.

Also, healthy lifestyle must be valued and consolidated in the school context, through local public policies that favor the support to physical activities, with the adequacy of physical environments and the integration of physical exercises in after school activities and the promotion of healthy eating, with restriction of processed and ultra-processed foods offered in school canteens ${ }^{(33)}$.

These results should be considered in the implementation of strategies and interventions for adolescents, focused on reflections and clarifications on the exposure of body stereotypes, avoiding implications that elevate the risk of disorders in adult life. The results could subsidize the professionals who deal with adolescents to work the topic "body in adolescence".

\section{CONCLUSION}

In this study, a relevant part of public-school adolescents was dissatisfied with their body image, which is associated to sex and nutritional status. Female adolescents showed higher prevalence of dissatisfaction due to excess weight, and male adolescents due to weight deficit. Body image dissatisfaction showed higher proportion among adolescents with nutritional deviations.

It is expected that the dissemination of information obtained in this study encourages the reflection of health professionals and of the school community that act directly with this age group regarding the need to consider this variable in the assistance to these groups. These results may facilitate an early assistance to a condition that may lead to other disorders, with mental suffering and impairment of the individual's functionality. Also, new studies in this field should be developed, especially in the investigation of body image dissatisfaction and the relation with mental disorders in adolescents.

\section{FUNDING}

Fundação de Amparo à Pesquisa do Estado de Minas Gerais (Fapemig) and scholarship granting by the Coordination of Higher Education and Graduate Training (CAPES).

\section{REFERENCES}

1. Castro IRR, Levy RB, Cardoso LO, Passos MD, Sardinha LMV, Tavares LF, et al. Imagem corporal, estado nutricional e comportamento com relação ao peso entre adolescentes brasileiros. Cienc Saúde Coletiva. 2010;15(Supl. 2):3099-4108. doi: 10.1590/S1413-81232010000800014

2. Marques MI, Pimenta J, Reis S, Ferreira LM., Peralta L, Santos MI, et al. (In)Satisfação com a imagem corporal na adolescência. Nascer Crescer [Internet]. 2016[cited 2018 Jan 06];25(4):217-21. Available from: http://www.scielo.mec.pt/pdf/nas/v25n4/v25n4a04.pdf

3. Lira AG, Ganen AP, Lodi AS, Alvarenga MS. Uso de redes sociais, influência da mídia e insatisfação com a imagem corporal de adolescentes brasileiras. J Bras Psiquiatr. 2017; 66(3): 164-71. doi: 10.1590/0047-2085000000166

4. Pelegrini A, Petroski EL. The association between body dissatisfaction and nutritional status in adolescents. Human Movement. 2010; 11(1):51-7. doi: 10.2478/v10038-010-0001-7

5. Felden EPG, Claumann GS, Sacomori C, Daronco LSE, Cardoso FL, Pelegrini A. Fatores sociodemográficos e imagem corporal em 
Perception of body image and nutritional status in adolescents of public schools Pinho L, Brito MFSF, Silva RRV, Messias RB, Silva CSO, Barbosa DA, et al.

adolescentes do ensino médio. Ciênc Saúde Coletiva. 2015; 20(11): 3329-37. doi: 10.1590/1413-812320152011.00212015

6. Petroski EL, Pelegrini A, Glaner MF. Motivos e prevalência de insatisfação com a imagem corporal em adolescentes. Cienc Saúde Coletiva. 2012;17(4):1071-7. doi: 10.1590/S1413-81232012000400028

7. Lewer M, Bauer A, Hartmann AS, Vocks S. Different facets of body image disturbance in binge eating disorder: a review. Nutrients. 2017; 9 (12). pii: E1294. doi: 10.3390/nu9121294. doi: 10.3390/nu9121294

8. Karazsia BT, Murnen SK, Tylka TL. Is body dissatisfaction changing across time? a cross-temporal meta-analysis. Psychol Bull. 2017; 143(3):293-320. doi: 10.1037/bul0000081

9. Sadock BJ, Sadock VA, Ruiz P. Synopsis of psychiatry behavioral sciences: clinical psychiatry. 11 Ed. Wolters Kluwer; 2015.

10. Côrtes MG, Meireles AL, Friche AADL, Caiaffa WT, Xavier CC. O uso de escalas de silhuetas na avaliação da satisfação corporal de adolescentes: revisão sistemática da literatura. Cad Saúde Publica. 2013;29(3):427-44. doi: 10.1590/S0102-311X2013000300003

11. Pelegrini A, Coqueiro RS, Beck CC, Ghedin KD, Lopes AS, Petroski EL. Dissatisfaction with body image among adolescent students: association with socio-demographic factors and nutritional status. Cienc Saude Coletiva. 2015; 19(4):1201-8. doi: $10.1590 / 1413-81232014194.09092012$

12. Laus MF, Kakeshita IS, Costa TMB, Ferreira MEC, Fortes LS, Almeida SS. Body image in Brazil: recent advances in the state of knowledge and methodological issues. Rev Saúde Pública. 2014; 48(2): 331-46. doi: 10.1590/S0034-8910.2014048004950

13. Miranda VPN, Conti MA, Bastos R, Ferreira MEC. Insatisfação corporal em adolescentes brasileiros de municípios de pequeno porte de Minas Gerais. J Bras Psiquiatr. 2011; 60(3): 190-97. doi: 10.1590/S0047-20852011000300007

14. Ministério da Saúde (BR). Orientações para a Coleta de e Análise de Dados Antropométricos em Serviços de Saúde. Norma Técnica do Sistema de Vigilância Alimentar e Nutricional - SISVAN. Série G. Estatística e Informação em Saúde. Brasília, DF, 2011.

15. Onis M, Onyango AW, Borghi E, Siyam A, Nishida C, Siekmann J. Development of a WHO growth reference for school-aged children and adolescents. Bull World Health Organ [Internet]. 2007 [cited 2018 May 30];85(9):660-7. Available from: https://www.ncbi.nlm.nih.gov/ pubmed/18026621

16. Thompson MA, Gray JJ. Development and validation of a new body-image assessment scale. J Pers Assess [Internet]. 1995 [cited 2018 Feb 03];64(2):258-69. Available from: https://www.ncbi.nlm.nih.gov/pubmed/7722852

17. Conti MA, Latorre MRDO. Estudo de validação e reprodutibilidade de uma escala de silhueta para adolescentes. Psicol Estud 2009;14(4):699706. doi: 10.1590/S1413-73722009000400010

18. Madrigal-Fritsch H, Irala-Estévez J, Martínez-González MA, Kearney J, Gibney M, Martínez-Hernández JA. Percepción de la imagen corporal como aproximación cualitativa al estado de nutrición. Salud Publica Méx [Internet]. 1999[cited 2018 Mar 23];41(6):479-86. Available from: https://www.scielosp.org/article/ssm/content/raw/?resource_ssm_path=/media/assets/spm/v41n6/v41n6a06.pdf

19. Voelker DK, Reel JJ, Greenleal C. Weight status and body image perceptions in adolescents: current perspectives. Adolesc Health Med Ther. 2015;6:149-58. doi: 10.2147/AHMT.S68344

20. Costa NA, Lima NV, Pegolo GE. Insatisfação corporal e rastreamento do risco para transtornos alimentares em adolescentes. Adolesc Saude [Internet]. 2016[cited 2018 Apr 05];13(1):16-26. Available from: http://adolescenciaesaude.com/detalhe_artigo.asp?id=565\#

21. Bašková MJH, Holubčíková J, Baška T. Body-image dissatisfaction and weight-control behaviour in slovak adolescents. Cent Eur J Public Health [Internet]. 2017[cited 2018 Feb 24];25(3):216-21. Available from: https://www.ncbi.nlm.nih.gov/pubmed/29022681

22. Arenas JJS, Martínez AOR. Relationship between self-esteem and body image in children with obesity. Rev Mex Trastornos Alimentarios [Internet]. 2015 [cited 2018 May 02];6(1):38-44. Available from: https://www.sciencedirect.com/science/article/pii/S2007152315000075

23. Ferreira AA, Nogueira JD, Wiggers I, Fontana KE. Composição e percepção corporal de adolescentes de escolas públicas. Motri [Internet]. 2013 [cited 2018 Jan 10];9(3):19-29. Available from: http://www.scielo.mec.pt/pdf/mot/v9n3/v9n3a04.pdf

24. Pereira JAR, Ramos GRV, Rezende EG. Percepção corporal em adolescentes de baixa condição socioeconômica. Rev Med Minas Gerais [Internet]. 2012 [cited 2018 May 03];22(3):301-7. Available from: http://www.rmmg.org/artigo/detalhes/81

25. Fortes LS, Cipriani FM, Coelho FD, Paes ST, Ferreira MEC. Does self-esteem affect body dissatisfaction levels in female adolescents? Rev Paul Pediatr [Internet]. 2014 [cited 2018 Apr 02;32(3):236-40. Available from: http://dx.doi.org/10.1590/0103-0582201432314

26. Pena GG, Mendes JCL, Silveira APS, Reis TCR, Vieira RG, Souza NSS, et al. Comportamentos de risco para a saúde de adolescentes da rede pública de ensino. Adolesc Saude [Internet]. 2016 [cited 2018 Jan 16];13(1):36-50. Available from: http://www.adolescenciaesaude.com/ detalhe_artigo.asp?id=544

27. Pinho L, Flávio EF, Santos SHS, Botelho ACC, Caldeira AP. Excesso de peso e consumo alimentar em adolescentes de escolas públicas no norte de Minas Gerais, Brasil. Cienc Saúde Coletiva[Internet]. 2014 [cited 2018 Mar 04];19(1):67-74. Available from: http://www.scielo.br/pdf/ csc/v19n1/1413-8123-csc-19-01-00067.pdf

28. Pelegrini A, Coqueiro RS, Beck CC, Ghedin KD, Lopes AS, Petroski EL. Dissatisfaction with body image among adolescent students: association with socio-demographic factors and nutritional status. Cienc Saúde Coletiva [Internet]. 2015 [cited 2018 May 04];19(4):1201-8. Available from: http://www.scielo.br/pdf/csc/v19n4/1413-8123-csc-19-04-01201.pdf

29. Santos CF, Castro IRR, Cardoso LO, Tavares LF. Agreement and association between different indicators of body image and body mass index in adolescents. Rev Bras Epidemiol. 2014;17(3):747-60. doi: 10.1590/1809-4503201400030014 
30. Bucchianeri MM, Arikian AJ, Hannan PJ, Eisenberg ME, Neumark-Sztainer D. Body dissatisfaction from adolescence to young adulthood: findings from a 10-year longitudinal study. Body Image [Internet]. 2013 [cited 2018 Feb 07];10(1):1- Available from: https://www.ncbi.nlm. nih.gov/pubmed/23084464

31. Cecon RS, Franceschini SCC, Peluzio MCG, Hermsdorff HHM, Priore SE. Overweight and body image perception in adolescents with triage of eating disorders. Scientific World J. 2017 [cited 2018 Jun 09];2017:1-6. Available from: https://www.hindawi.com/journals/ tswj/2017/8257329/

32. Souza AC, Alvarenga MS. Insatisfação com a imagem corporal em estudantes universitários: uma revisão integrativa. J Bras Psiquiatr. 2016;65(3):286-99. doi: 10.1590/0047-2085000000134

33. Bezerra MA, Carvalho EF, Oliveira JS, Leal VS. Saúde e nutrição em escolas públicas e privadas de Recife. Rev Bras Saude Mater Infant. 2017; 17(1): 191-200. doi: 10.1590/1806-930420170001000011 